\title{
Meta
}

Journal des traducteurs

Translators' Journal

\section{Made in Quebec, Reviewed in Toronto: Critical Response to Translated Quebec Theatre}

\section{Jane Koustas}

Volume 40, numéro 4, décembre 1995

URI : https://id.erudit.org/iderudit/003345ar

DOI : https://doi.org/10.7202/003345ar

Aller au sommaire du numéro

Éditeur(s)

Les Presses de l'Université de Montréal

ISSN

0026-0452 (imprimé)

1492-1421 (numérique)

Découvrir la revue

Citer cet article

Koustas, J. (1995). Made in Quebec, Reviewed in Toronto: Critical Response to Translated Quebec Theatre. Meta, 40(4), 529-539.

https://doi.org/10.7202/003345ar

\section{Résumé de l'article}

L'auteur étudie l'accueil fait aux pièces de théâtre québécoises à Toronto entre 1970 et 1982. Elle compare la réaction de différentes critiques en portant une attention particulière aux analyses touchant les traductions et les traducteurs. Elle montre que les critiques font preuve de "Torontocentrisme" en ignorant l'importance de la traduction ou en recherchant des traductions plus compréhensibles pour le public torontois. 


\title{
MADE IN QUEBEC, REVIEWED IN TORONTO: CRITICAL RESPONSE TO TRANSLATED QUEBEC THEATRE
}

\author{
JANE KOUSTAS \\ Brock University. St. Catharines. Canada
}

\begin{abstract}
Résumé
L'autcur étudie l'acrueil fait aur pièces de théâtre québécoises d Toronto entre 1970 et 1982. Elle compare la réaction de différentes critiques en portant une aftention parficuliere aux analyse's truchant le's traductions et les traducteurs. Elle montre que les critiques font prewse de "Torontocensrisme" en ignorant l'importance de la traduction ou en recherchant des traductions pius compréhensibles pour le public toronsois.
\end{abstract}

Abstract

The aushor sfudies the reception of Quehec plavs in Toronto between 1970 and 1982. She compares the response of different critiques. focussing on analyses of translations and translators. The author show's that critics are guilty of being "Toronto-centric," hy ignoring the importance of translation or secking more easily understandable translations for Toronto audiences.

In Sociocritique de la traduction, Annie Brisset accuses Quebec theatre translators and companies of eliminating or downplaying the alterity of non-Quebec theatre in their translations, adaplations, parodies or reappropriations of foreign works (Brisset 1990). Rather than acting as mediators, translators aim to integrate foreign works into the Quebec nationalist social discourse and thus use these plays to establish a "national" theatre. The author stresses Quebec's indifference towards or even disdain of English Canadian theatre (p. 47) in particular and indicates that only $2 \%$ of all "foreign" plays produced by the major theatre companies between 1968 and 1988 were from English Canada. Citing the following definition by Antoine Berman, she concludes that Quebec theatre is essentially ethnocentric:

Ethnocentrique signifiera ici : qui ramène tout à sa propre culture. à ses normes et valeurs et considère ce qui est situé en dehors de celle-ci - l'Étranger - comme négatif ou tout juste bon à être annexé. adapté. pour accroître la richesse de cette culture. (Brisset 1990:111)

What then can be said about Quebec theatre in Toronto? Robert Wallace is enthusiastic about the popularity of French-Canadian theatre which has become "a staple of the Toronto season" (Wallace 1999): 216). He argues however that efforts to bridge the cultural gap have sometimes been sabotaged because of a failure to acknowledge, accept and account for cultural differences as a part of transferring theatre from one culture to another (Wallace 1990: 216). This has sometimes rendered "wrong-headed" (id: 217) English Canadian productions of French-Canadian plays as well as a critical response that somewhat ignores "where a play is coming from": Toronto reviewers exhibit a Torontocentered attitude that brings into question the fairness of their reviews. He states:

Indeed my general concern with the reception of Québecois plays in Toronto originates with my discomfort over the attitudes with which they often appear to be approached, not just by the critics who review them but also by the companies that produce them. In a word, I would 
typify these attitudes as Toronto-centric, adding to the historical complaint... that Toronto's anistic institutions suffer from an arrogance that leads them to either appropriate or dismiss whatever appears to them as genuinely different. (id.: 220)

Like Brisset then, Wallace suggests that ethnocentrism interferes with genuine exchange. He recommends that critics. as well as all those attending and involved in the production, avail themselves of a knowledge of place in order to "understand it's (the play "s| context of time and place" (id.: 218). Wallace also suggests that critics recognize the importance of the mediation of translation and the "degree to which the translation alters the original and creates, in a sense, a new play" (1990: 221).

This article will examine the critical response to translated Quebec theatre in Toronto from 1970 to 1982' while recognizing, as does Wallace, that reviews are the "subjective reactions of individuals whose perceptions are often not shared by others" (1990: 217). Indeed this study frequently considers the divergent response provided by the daily press as well as by other sources?2. In the light of Brisset's and Wallace's studies. particular attention will be paid to the importance attributed to the translation and translator as well as to critical response to the question of place. This study argues that by ignoring the importance of the translator or by crediting the translation only when it renders the work more familiar. Toronto critics display an attitude similar to that discussed by Brisset.

Jean-Claude Germain's introduction to Toronto with Notes from Quebec (Theatre Passe Muraille, from May 7. 1970) was Toronto's first experience with "joual" in translation and with a new type of Quebec theatre which spoke of a different, post Quiet Revolution Quebec. It was, according to the critics, unsuccessful. The play was described as "an absurdist soap opera" (H. Whittaker, Glohe and Mail, May 8 1970) which, while "often interesting and occasionally funny" (Dan Rubin, Star, May 8 1970), remained "sophomoric and amateurish" (id.). While condemned for these reasons, the play"s "québécitude" also worked against it: it was judged to have lost "some pertinence in the translation" (H. Whittaker, $i d$.) and to have lost impact in its uprooting from Quebec to Toronto (D. Rubin, $i d$.). It was thus "over the head" of at least one critic who was also offended by Germain's, or the translator's, use of four letter words (Dubarry Campeau. Telegram, May 8 1970). The translator's name was not mentioned.

The negative reaction elicited by a play's québécitude as well as by the use of "joual" was even more evident in Jean Barbeau's Toronto experience. Critics saw in the production of Jean Barbeau's Manon Lastcall and The Way of Lacross (W.W. Theatre Productions. Poo Alex. May 1-27 1972) "one hit, one miss" (H. Whittaker, Globe and Mail, May 12 1972). Monon Lastcall was little more than "a tiresome farce" (U. Kareda. Star. May 12 1972) that "misfired" (H. Whittaker, $i d$.$) . It was suggested that "the play$ suffer|ed| from being aimed specifically at a Quebec audience" (Grace Richardson) thus rendering the social criticism irrelevant. The jokes on Parisian and Quebec French for example did not "come across" (G. Richardson). More importantly, the critics, and according to them, the audience, was particularly unsympathetic or insensitive to the play's political message: Lacross's final outburst "fell flat" (G. Richardson). Searching for the reasons for Lacross's arrest, and apparently unaware that the play was based on the actual arraignment of a political demonstrator, $H$. Whittaker commented that the "play's accusatory drive [was] weakened" (H. Whittaker, $i d$.). While noting the play's use of "a quality closely identified with Quebec"s separatist pangs." Whittaker, like other critics failed to acknowledge or explain the importance of the political background notably the Octoher Crisis. Urjo Kareda was more sensitive to both the linguistic and cultural problems involved in transporting this new type of theatre and to the Toronto audience's difficulty in understanding or appreciating it. He pointed out the importance of "the sound 
of language" (see Wallace 1988: 9: and Leonard 1988) stating that "Barbeau uses words with exceptional muscularity and vigour." He noted as well the importance of "use of words that contain other words much as social structures contain other social structures" and the failure of the translation, "safe, self-deprecating and listless" to convey this. U. Kareda further commented on the difference between the French and English versions, which ran at the same time, noting that the latter suffered because of the "wilful obliteration of the ceremonial |religious] nature of the play," dropped because it could have proved "too remote" for the Toronto audience (Urjo Kareda, Star, May 12 1972). He recognized as well the importance of cultural difference or the question of place in Barbeau's work and that translating and transposing such plays could prove to be "a troublesome poinı."

Particularly unappreciative of both Barbeau plays were the mothers of the elementary school children who, through some total miscalculation of WASP sensibilities, had been given free tickets. The students may have happily snickered through the performance but the mothers, "enraged over obscene language and scene" stormed out claiming. "those people should be put in a mental institution for putting on something like that" (Robert MacDonald, Sun. April 8 1972).

Michel Tremblay's tremendous success in Toronto, due in part to the efforts of Bill Glassco and John Van Burek, has been the subject of numerous studies. Toronto critics recognized in Tremblay "a writer of apparent power and tremendous drive" (H. Whittaker. Globe and Mail. Nov. 15 1972) at the opening of Forever Yours Marie-Lou (Tarragon Theatre, Nov. 14-Dec. 10 1972). The enthusiasm was not however unanimous. Described as "a fascinating play" (U. Kareda. Star. Nov. 15 1972) it was also judged to be "repetitious and outdated" offering only some "familiar novelty" (H. Whittaker. id.). The reaction to the translation was also mixed. Described as "splendid" (U. Kareda, id.), it was also blamed for the play's loss of impact $(\mathrm{H}$. Whittaker, id.). However in spite of the critics' somewhat mixed reaction, the attendance figure of $80 \%$ indicates that this production did indeed set the stage for Tremblay's future successes. Paula Dancy affirms, "Tarragon had shown that there was, in Toronto, an audience for Tremblay" (Dancy 1985: 27).

Marie-Lou's return to Toronto (Theatre Plus. St. Lawrence Centre for the Arts, June 4-21 1975) was described as a "riveting performance" (George Anthony, Sun, April 6 1975) in which the director made "the most of the playwright's work" (Joseph Erdelyi, Ottawa Citizen. April 6 1975). The unanimously positive reaction to the text suggests indeed that the Toronto audience had "had more of an opportunity to study his [Tremblay's] style enabling it to spot the surging currents beneath the dazzling movement of the actor stream" (H. Whittaker. Globe and Mail. June 5 1975). U. Kareda, while maintaining his high opinion of the "beautifully controlled and constructed" play (Star. June S 1975). found that Theatre Plus had made "a minus of Tremblay."

The play succeeded however in spite of, not because of, its Quebec origins. The product of a "church-ridden state." the play was deemed to have lost some "courage" either through "transplant or translation" (H. Whittaker, Globe and Mail, 1975). However while being simultaneously "personal, regional and universal" (H. Whittaker), the play could "flourish without a political analysis" (U. Kareda. Star, May 15 1972) and could "reach beyond its point of origin" (H. Whittaker, Globe and Mail. 1972). The Star critic further downgraded the importance of the play's and Tremblay's Quebec origins by stating. "Tremblay himself would say that he is a Quebec playwright, not Canadian, but never mind" (U. Kareda, Star, June 15 197.5).

Anne Hébert's Le temps sauvage (University Alumnae Dramatic Production. Firehall Theatre. Nov. 23-Dec. 9 1972) was compared to Tremblay's play staged only ten 
days earlier and was described as another "symbolic analysis of Quebec's problems seen dramatically in terms of family contact" (U. Kareda, Star. Nov. 27 1972). The text, though of "undeniable interest." lacked "style and vigour" (H. Whittaker, Glohe and Mail, Nov. 24 1972) and needed "more shape" (U. Kareda, Star. Nov. 24 1972) thus suggesting to Toronto critics that Hébert was "more novelist than playwright" (H. Whittaker, $i d$.). The Iranslation by Elizabeth Mascall was judged to be a "fair stab" (U. Kareda. $i d$.). Both critics labelled it a "Quebec" play.

Gélinas" Mortier (Factory Lab Theatre. Dec. 6-21 1972) received little critical attention and, as part of a short play festival that became "a killing marathon" was described as only a "dreary marriage game" (U. Kareda, Star, Dec. 7 1972).

Michel Tremblay made a sensalional return to Toronto with Les Belles-Sorurs (The St. Lawrence Centre Repertory Theatre Company, March 31-April 28 1973). Described as a "milestone play, a high point for the St. Lawrence Centre" $(H$. Whittaker, Glohe and Mail, March 4 197.3) and "a breath of life that was notably Canadian" (U. Kareda, Star. March 4 1973) it was viewed as a Montreal or Quebec play which offered "a penetrating vision of Quebec society" (David McCaughna. Toronto (itizen. March 20 1973). The production thus raised interesting questions about the Toronto audience's capacity to appreciate and understand Tremblay and Quebec theatre in general. U. Kareda urged the large crowds gathered at the O'Keefe Centre for Mose over Mrs. Markham to "go next door" (Star. March 7 1973) but questioned the Toronto theatregoers' willingness and ability to "jump across the |cultural $\mid$ intersection" to see "the municipally financed, locally produced. 10,0K() times more entertaining Les Belles-Stzurs." H. Whittaker referred as well "to a kind of mute edged condescension indelibly WASP" and hoped that "possibly later Toronto audiences [would] respond less consciously and [would] be able to laugh directly without striking any bicultural notes" $(H$. Whittaker, $i d$.). it was not clear for example whether the Toronto audience who stood and cheered at the end of the play did so to show their praise for the production or their respect for the national anthem with which it ends (D. McCaughna).

René Dionne's translation was judged to be unacceptable only three weeks before the opening. Bill Glassco and John Van Burek yuickly produced a second English version which. deemed "splendid and brilliant" (U. Kareda. Star. April 4 1973) and praised for having successfully captured "the flavour and earthiness of the language" (D. McCaughna, id.), was also described as "a massacre" (Myron Galloway, Montreal Star, March 4 1973). The latter critic also condemned the actresses" feigned accents claiming that they ranged "from Maine to Manchester" and concluded that Tremblay's play had nothing to say "if the French-Canadian flavour | was| missing for it |was| essentially a portrait of a very special segment of French-Canadian urban life." Even U. Kareda, who praised the translation in an article in which he discussed the difficulties in translating Tremblay, stated that the "play's strong political implications would be largely lost in English" (Star. March 26 1973).

Tremblay's En piece's détachées. (New Theatre, Bathurst Street, March 5-April 15 1974) rather "disgustingly retitled Momtreal Smoke Mear" (U. Kareda, Star. March 8 1974). did not, according to most critics, rank with his other works (D. McCaughna, Toromo (itizen, March 29 1974). The production gave the impression of "a novel sliced up into theatrical segments" (H. Whittaker, Glohe and Mail, March 8 1974) which did "add up to a theatrical experience though not quite a play" (U. Kareda, id.). Tremblay was praised however for his role as "a first rate social critic" ( $H$. Whittaker, $i d$.). After Les Belles-Sorurs however, the play was criticized for being merely a repetition of "more Montreal misery" (D. McCaughna, idl.). H. Whittaker questioned the Toronto audience's willingness to accept Montreal's "squalid" side instead of the "quaint. charming. historic 
vision of Montreal to which / we/ have been exposed to in the past" (March 8 1974). The translation did not receive any critical attention.

Michel Gameau's Four to Four (Tarragon, March 30-April 28 1974) suffered from dealing only with "Quebec women" whose background (D. McCaughna, Toronto Citizen. March 12 1974) was too "exotic in an Ontario setting" (H. Whiltaker. Globe and Mail. April 7 1974). It was criticized for "thrusting itself in (ourl faces with too much unnecessary venom" (D. McCaughna. $i d$.) with its "roaring choruses, overblown images and a quest for poetic importance which seriously damage|d| the work's early truthfulness" (U. Kareda. Star. March 1 1974). The play was also acclaimed as "a winner, a significant work" (Gregory Glover, Sun, April 2 1974) and Garneau was identified as a "brave dramatist" (H. Whittaker, April 1 1974). The translators were mentioned in the Star and Globe reviews though neither explained how their work may have affected the production.

Described as an "event" (Bruce Kirkland, Star, Jan. 11 1977), a "landmark" (Charles Pope, Scene Changes, Jan. 1977), a "legend" (Gina Mallet. Star, Jan. 14 1977) after which "Canadian theatre | was| not quite the same" (David Ossea, Varsity, Jan. 21 1977). Tremblay's Hosanna earned the playwright the reputation of "the darling of the critics and the chosen one of the Toronto theatre scene" (Ed Bean, Varsity, Sept. 29 1974)4. A resounding success ${ }^{5}$ when it first opened at the Tarragon Theatre (May 15-June I 1974), it continued to draw Toronto crowds in three subsequent productions (Global Village Theatre. Sept. 6-Oct. 4 1974: Toronto Workshop Productions Jan. 13-Feb. 14 1977: NDWT Theatre, March 11-22 1980) and also ran at the Bijou Theatre on Broadway.

After its premiere at the Tarragon, critics described Hosanna as "a shimmering production" (U. Kareda. Star. May 16 1974). "a brilliant exploration of a ménage à deux" (Toronto Citizen. May 24 1974), a "heart-pounding tour de force" (H. Whittaker. Glohe and Mail, May 16 1974) and a "full blooded [... . powerfully written drama" (Myron Galloway, Montreal Star, June 11 1974). It was undoubtedly "Tremblay's most successful play [to date]" (D. McCaughna. Motion. July / Aug. 1974) and one of the most popular plays ever to be written by a Canadian playwright (D. Ossea, Varsity, Jan. 2 1977).

The critics, especially those reviewing later productions. were not unanimously enthusiastic about the play"s literary merit. It was described as a "weak Tremblay play" (Audrey Ashley. Ottawa Citizen. Oct. 7 1974) a "melodramatic" play (G. Glover, Sun, May 17 1974) in which the writing was "not as strong as in some of Tremblay's other works" (D. Ossea. Varsity. Jan. 21 1977). The play's success was instead often attributed to the combined contribution of a "triumvirate of exceptional talents. Tremblay, Glassco, Monette" (John Fraser, (ilobe and Mail, Sept. 14 1974), or a "perfect fusion between writer and actor" (G. Glover, id.); playwright, translator, director and actor were equally credited with having made "another major contribution to the Canadian theatre scene" (D. Ossea, Varsity, Jan. 21 1977).

In preparation for its Broadway debut, Hosanna returned to the Global Village theatre and was pronounced not only "in trim for Broadway" (J. Fraser, id.) but "one of the best pieces of theatre [you "ll] find in Toronto |this| season" (E. Bean, Varsity, Oct. 20 1974). Full houses (A. Ashley, id.) and rapid ticket sales (G. Anthony, Sun, Sept. 13 1974) proved that indeed the "magic was still there" (G. Anthony, id.).

Critics responded to the Toronto Workshop's production of Hosanna less enthusiastically. Though still "a fine evening of theatre" (D. Ossea, id.) and one of the "most satisfying evening in theatre in Toronto (G. Mallet. Star. Jan. 14 1977). Hosanna's dazzle had "worn a little thin" (D. Ossea, id.). Criticism was levelled primarily at the lack of plot development (D. Ossea, $i d$.), the timing of Cuirette's return (J. Herbert, Onion, Feb. 16 
1977). as well as at Tremblay"s "corny and trite" treatment of homosexuality (John Herber, $i d$.) which was described as a "tiresome emphasis of obvious" (M. Porter, Sum. Jan. 17 1977). The mixed reaction could indicate that indeed the "production's most serious flaw [was] perhaps its nostalgic attempt to recreate its own past glories" (D. Ossea, $i d$.). This was confirmed by the critics' limited response to the NDWT production when once again attention was drawn to the play's structural problems (Katherine Gilday. Star. March 16 1980). Hosanna was perhaps "a trifle tattered" (Ray Conlogue, Globe and Mail. March 17 1980).

Bonjour, la Bonjour (Tarragon Theatre. Feb. 1-March 16 197.5) did not evoke the unanimously positive response generated by Hosamma's premiere. According to Paula Dancy, it was clearly the weakest of the Tarragon Tremblay productions (Dancy 1985: 93). The play was also described as "the most fascinating of Tremblay"s work" (H. Whittaker, Glohe and Mail, Feb. 3 1975). Thanks to Bill Glassco's "thoughtful and respectful interpretation" which rendered the play "void of the rough joual" and thus able to "serve the Ontario audience well" it was in "no way a reproduction of the Quebec original" (H. Whittaker, $i d$.). Urjo Kareda described it as "the most deeply flawed of his plays" (Star, Feb. 3 1975). P. Dancy maintains that Tarragon's ambiguous treatment of the incest issue, the conclusion of which was both "unthinkable and sentimental" (U. Kareda, id.) was largely responsible for its poor reception (Dancy 198.5: 47).

Billed with Carol Bolt's Shelter. Tremblay's Surprise, Surprise. (Toronto Arts Productions. St. Lawrence Centre. Oct. 22-Nov. 8 1975), was described as "just a fragment" (J. Fraser. Glohe and Mail, Oct. 23 1975), "a short sketch" (John Wilson, Varsity, Nov. 14 1975) and a "revue sketch" (M. Porter. Sun. Oct. 24 1975). "A taughtly structured microcosm of ideas completely Canadian in content" (C. Pope, Scene Changes). "a defily written and amusing morsel" (D. McCaughna, Star. Oct. 23 1975) "rich in Quebec ambience and humour" (M. Porter. id.), Surprise, Surprise generated a positive though limited response?

The Black Cat Cabaret's production of La Duchesse de Langeais (May 22-June 28 1980) suffered due to the age of the play". Labelled "a left-over from primal scream of gay lib" (Kaspars Dzeguze. Sun, June 1980), this "minor Tremblay" was judged to be a "bad joke" whose subject, transvestism, had become a "bore" (G. Mallet, Star. June 5 1980) and had since been more amusingly dealt with by films such as La cage anx folles (Debra Sharp. Glohe and Mail. June 6 1980). The latter critic praised Tremblay's use of language but did not mention that John Van Burek was the translator. The Sun critic noted Van Burek's "happy enough translation" but found the narrative at odds with the central actor's style.

With St. Carmen of the Main (Tarragon Theatre, Jan. $11-F e b .26$ 1978), a "tragedy pure and simple" (R. Conlogue. Glohe and Mail. Jan. 16 1978). Tremblay had mixed results. Both "preposterous and touching" (Richard Eder, New' York Times, Feb. 2 1978). the play. according to one critic. "never rose above the level of a not very good soap opera" (Stephen Mezei, Onion, Feb. 8 1978). However it was also described as "an absolutely fascinating gesture by a powerful playwright" ( $R$. Conlogue, $i d$.). The use of the chorus as well as the translation evoked an equally mixed reaction. The chorus which was endowed "with incredible panache" and given a choral ode that was "full of poetic imagery" ( R. Conlogue, id.) was nonetheless described as "gimmicky." "a chorus of freaks" (Joseph Erdelyi, Ottawa (irizen. Jan. 17 1978) and blamed for making the play "worse" (S. Mezei, id.). P. Dancy points to Tremblay"s inability to combine this ancient style with modern slang as the source of many of the problems facing the play (Dancy 1985: 63). Similarly the translation. praised by one critic for "maintaining a skillful retention of the French-Canadian disposition" (M. Porter. Sum, Jan. 16 1978) was also accused 
of "not capturing much of the nuance, the savour" (Brian Freeman, Star, Jan. 15 1978) and blamed, more importantly, for not conveying the play's "political fable." The play whose "spirit" was lost on the Toronto audience seemed "curiously uprooted" (B. Freeman, id.). Only Freeman and Eder mentioned the play's political message but the latter condemned the political vision as "preposterous" while not explaining what the message really was. Ray Conlogue commented on the "long, lyrical speeches" without mentioning the translator.

Roland Lepage's Le temps d' une vie, though recognized for its literary merit. suffered from its limited regional subject matter. Bryan Johnson stated, "My problem - and one I suspect I will share with many others - is the subject matter itself" (Globe and Mail. May 15 1978). Deemed "worth waiting for" (B. Freeman, Star, April 15 1978), the play earned Lepage praise for the "loving care with which he treated his subjects" (J. Erdelyi, Ottawa Citizen. April 18 1978) and for his "fine dialogue" and "deft sense of pacing" (Bryan Johnson. Glohe and Mail, May 15 1978). However, in spite of Shiela Fischmann's "excellent translation (B. Johnson, $i d$.), the play remained a "lyrical look at simple habitant life" (J. Erdelyi. Ottawa Citizen. April 15 1978), an exploration of the "rural roots of French Canada" (B. Freeman, id.) and essentially a play "about the soul of Quebec" (Jamie Porter. Calgary Herald. April 30 1978). It was therefore, according to the critics, 100 remote for the Toronto audience and questions were raised about the Toronto public's "burning interest in a lyrical epic about one woman's life in rural Quebec" (B. Johnson, id.).

Tarragon's production of Damnée Manon, Sacrée Sandra (Tarragon Theatre, Nov. 20-Dec. 22 1979) received mixed reviews and was a source of "controversy, curiosity and confusion" (Dancy 1985: 70). Though review articles frequently pointed to production faults. Tremblay was also held responsible for the confusion (Dancy 1985: 73). Condemned for its lack of action which rendered the play "boring" (M. Porter, Sun, Nov. 25 1979). and described as "an unworthy play" (G. Mallet, Star. Nov. 23 1979), it was also judged to be "a rewarding ritual experience" (R. Conlogue, Globe and Mail, Nov. 23 1979). No critics commented on the translation nor on the play's social or political message.

The Impromptu of Outremont (Tarragon Theatre, May 22-June 28 1980). Toronto's first glimpse at Tremblay`s interpretation of the life of the upper classes, received a similar mixed reaction. The "pointless bickering and mechanical dialogue of Tremblay's rich bitches" (Art Cuthbert, Star, April 23 1980) was also described as an "engrossing, thickly textured play" which included "beautifully written, aria-like monologues" (R. Conlogue. Globe and Mail. May 23 1980). However, neither Conlogue nor any of the other critics credited the translator. Dancy suggests that directorial problems were to blame for the largely negative reaction (Dancy 1985: 95).

The "magic" (Norma Harris, Globe and Mail. Feb. 20 1982) of Jovette Marchessault's The Sage of the Wet Hens was largely lost on the Toronto audience either through "misdirection" that resulted in "much confusion" (N. Harris, id.) or as a result of a "poor translation of shameless literary pretention" that "drown the Wet Hens in a flow of classy prose" (G. Mallet, Star, Feb. 19 1982), the only mention of the translation. The audience's lukewarm reaction was also attributed to the cultural gap: the numerous allusions to the authors depicted as well as to the Catholic church as the key oppressor were losi on the Toronto audience (N. Harris, id.).

Roch Carrier's Celestial Bicycle suffered a similar fate. Though providing Albert Millaire, the star, with "an opportunity to do the things that superior actors do" (R. Conlogue, Globe and Mail, April 2 1982), the play was essentially "lost in a smoke screen" (G. Mallet, Star, April 2 1982). Toronto's less than enthusiastic response to this 
Quebec hit was once again attributed to the language barrier "which never seemed more inseparable" (G. Mallet, $i d$.) and to the cultural gap: it simply did not "work with the anglophone sensibility" (R. Conlogue, $i d$.). Neither critic commented on the translation.

Up until the arrival of Michel Tremblay on the Toronto English theatre circuit an average of only one Quebec play in translation was staged a year. However, from 19721980 Toronto audiences had the opportunity to see usually two, if not three, professional productions at least one of these heing a Tremblay play. Until Tremblay`s Toronto debut in 1972. Gratien Gélinas and Jacques Languirand were the most often produced playwrights (Marie O'Neill-Karch and Pierre Paul Karch 1984). However it is very evident that the seventies belonged to Tremblay. Though not all of his plays received the same enthusiastic reviews, the number of plays professionally staged prove the writer's popularity and the theatre companies' confidence in his ability to attract an audience. Other playwrights, Miche! Garneau, Jovette Marchessault and Roch Carrier, had only one play produced during this period. Furthermore, unlike Tremblay plays that were often staged by various companies, Hosanna in particular. each play was produced only once. However, as Paula Dancy points out. the initial decision to produce Tremblay was not without risks:

Tarragon made a daring decision to produce Tremblay hecause of his newness to the audience, his political aftiliation. which always leaked through (intentionally) into the theme and structure of his plays, his subject matter and the questionable quality of the translation of his plays. (Dancy 1985: Abstract)

This latter point, the problem of translating Tremblay's trademark "joual," is particularly serious (sec Homel and Simon 1988: 83-86) not only, as Vivien Bosley points out in her study of the Einglish version of Les Belles-Sirurs, because of the difficulty of finding an English equivalent, but because of "joual's" social, political and religious connotations and their repercussion in the text (Bosley 1980: 140-141).

This problem was far from surmounted. Tremblay himself claims that "the folkloric aspect of the language was missing" and that his plays will "never be as good in English as in French" (Usmiani 1979b: 37). When asked for his opinion of the English translations of Tremblay, André Brassard, the author's friend and colleague replied: "Fatal. With a text whose main asset is the language, you lose at least a third of it" (Usmiani 1979a: 41). Theatre critics described, for example, the translation of Tremblay's highly successful Hosanna as "occasionally clumsy" (Ed Bean, Varsity, Sept. 20 1974), "a repetition of the same four letter words" (A. Ashley. Ottan'a (itize"n, Oct. 7 1974) and as "too awkward and poetic" (David McCaughna, Motion. July / Aug. 1974) as well as "too shrill" (Jack Kapica, Globe' and Mail. Jan. 14 1977). However more important that the flow of the English version was its failure to convey, or the critics' and public's failure to recognize. the political and social connotations of Tremblay's work. Tremblay's success can not in fact be attributed to his ability to convey in popular language and to a sympathetic and informed audience, the sentiments and preoccupations of Quiet Revolution and post October Crisis Quebec nor to the fact that "when you're up to your ass in mud, any kind of solid ground is solid joy" (E. Bean. id.). His popularity is instead due to the Toronto public's and theatre critics" capacity and willingness 10 interpret Tremblay 's message as universal. Charles Pope stated:

[... no other (anadian dramatist has succeeded so completely in creating startling in terms of psychological insights as well as shock tactics and (sic) original theatre that is inherently Canadian without being provincial to the point of being incomprehensible to a non-Canadian audience. (Siene ('hange's, Jan. 1977) 
This confirms Wallace's observation that Toronto institutions, like their Quebec counterparts, need either to appropriate or dismiss work that is culturally different. In the case of Tremblay, the critical response dismisses the political, Quebec message while appropriating the universal elements. Hence Tremblay, the ardent Québécois nationalist, becomes "Toronto's favorite Canadian (emphasis added) playwright" (U. Kareda. Toronto Star, June 5 1975). This is particularly evident in the critical response to Hosanna.

Like all of Tremblay's plays, Hosanna contains a political message. As Tremblay himself stated:

I do not mean that they [Hosanna and Cuirette] are Quebec symbols or images of Quebec. But their problems with the wider society are political problems. Because they are the fringe group in society. this society in a way hates them. But they want to be happy and they want to he sometody. Hosanna is a man who always wanted to be a woman. This woman always wanted to be Elizabeth Taylor in Cleopatra. In other words, this Quebecois always wanted to be an English actress in an American movie about an Egyptian myth in a movie shot in Spain. In a way, that is a typically Québecois problem. For the past $\mathbf{3 0 0}$ years we were not laught that we were people, so we were dreaming about somebody else instead of ourselves. So Hosannes is a political play. (Anthony 1978: 283)

However, based on the critics' comments, the political aspect was largely missed. The play was instead seen as an exploration of the "poetics of love" (Agnes Kruchio, Excalibur, Sept. 19 1974), a "study of deception and humiliation and the loss of dreams" (U. Kareda, Toronto Daily Star. May 16 1974), a "sensitive delineation of a homosexual relationship" (D. McCaughna. Motion. July / Aug. 1974), or a "classic study of homosexual revenge" (George Anthony. Toronso Sun. Sept. 13 1974) by "the Canadian theatre's most compassionate poet of individual (emphasis added) isolation" (U. Kareda, id.). According to $\mathrm{H}$. Whittaker, Tremblay was talking about "deceptions and the need for them, and the loss of them and comfor in misery. About any (emphasis added) life, in fact" (Globe and Mail, May 15 1974).

Those critics who did recognize an attempt at a political message downplayed it claiming that such an allegory was "far-fetched" (Charles Pope, Scene Changes, Jan. 1977) or that "there was non inkling of such an idea to be found in the play no matter how hard one looked for signs" (John Hebert, Onion, Feb. 15 1977). More relevant to this study is D. McCaughna"s comment that though Tremblay is "a very political writer and all of his plays have dealt in one way or another with the condition of Quebec society, it does not hit home that this is a play which has a great deal to do with Quebec" (Motion. July ( Aug. 1974). However even those critics aware of the political message refused to acknowledge its importance. They chose instead to ignore from where the play was coming.

It has been previously argued (Koustas 1991) that up until the arrival of theatre resulting from the Quiet Revolution or Nouveau Théâtre québécois introduced by JeanClaude Germain. Jean Barbeau and Michel Tremblay. Toronto critics illustrated sensitivity. though one could argue somewhat patronizingly, to the question of place: productions were identified as being "Quebec" plays and some attention was paid to the play's social and historical context. With the introduction of joual, which posed more complex translation problems. and of the social and political issues associated with the Nouveau Théâtre québécois, which demanded greater understanding of a radically different "place" as well as of different theatre practices resulting in part from the collective theatre experience (see Wallace 1988 and Leonard 1988), critical response was less sympathetic towards plays" "québécitude" or Quebeckness: indeed a play"s "québécitude" seemed to work against it as it rendered it 100 remote for the Toronto audience. This study illustrated in fact that Michel Tremblay succeeded in Toronto as a Canadian, not Quebec, playwright 
due primarily to the universality, not québecitude, of his plays and to translations which diminished the "otherness" of his work. The negative reaction elicited by the distinctive Quebec flavour and subject of Lepage's. Hébert's, Marchessault's and Carrier's plays suggests a rejection of the unfamiliar and a reluctance to accept and interpret the importance of place when this ceased to be quaint and familiar. Indeed, with the exception of the Tremblay plays, six of the eight other plays studied were deemed too remote and the translator was frequently held responsible for alienating the Toronto audience. Only one review, Urjo Kareda's response to Manon Lastcall, criticized the translator for not respecting the "québécitude" of the original. Furthermore, in many of the cases studied. few critics even commented on the translation. By ignoring the contribution of the translation or by praising it only when it rendered the work more familiar. critics chose to further sever the play from its origins thus illustrating the Toronto-centric attitude discussed by Wallace. Must translators writing for the Toronto audience follow their Quebec counterparts example and transpose and reappropriate Quebec plays in order to make them more accessible, more universal and hence more popular? This raises the much studied yet never resolved dilemma of allegiance (see Blodgett 1983); should the translator "invade, extract and bring home" (Steiner 1975: 298) in order to attract a wider audience or "traduire oui, mais sans traduire" (Brault 1975: 50)? If indeed theatregoers and theatre critics attended Quebec plays to seize the opportunity "to learn, to know its differences, to understand Quebec's background and motivations" (H. Whittaker, Globe and Mail, Nov. 24 1972), the latter approach would be preferable and such would surely be the objective of any theatre translator, company, reviewer or patron genuinely concerned with bridging the cultural gap and who saw translation "as a vehicle through which cultures travel" (Homel and Simon 1988: 9). In this case it would be necessary. as Wallace suggests, to ask both from where the play was coming and to where it was going (Wallace 1990: 234) in order to guarantee successful and genuine exchanges between Canada's two main theatre communities.

\section{Notes}

1. Quebec theatre is understoxd for the purposes of this paper as "theâtre de langue française ecrit ou adapté par les dramaturges du Québec" as stated in Marie O'Neill-Karch and Pierte Paul Karch. "Le théatre québécois a Toronto". Le théâtre. 5. Ottawa, Les Presses de l'Université d’Ottawa. 1983. p. I0).

2. The plays will be studied in chronological order of production sexept in cases where the play was produced more than once. The various productions will then be studied logether for purposes of comparison.

3. Sec for example: Dancy 1985: (Jsmiani 1982 and 1979.

4. "Tarragen's box office receipts for /lowamma record allendance at $111 \%$ and $113 \%$ more than fowever Yours Marie'-lore and the most successtul show in Tarragen i first four years." (Dancy 1985: 36)

5. P. Dancy affirms that characterization, accompanied by stong performance was indeed the winning formula for mos of Tremblas is work. (1985: 34)

6. The Broalway profluction (from (xt. 14) which ran only three weeks, was a disappountment. (ritics remarked that "mixed reviews" (B. Kirkland. Srar, Jan. 11 1977) "deflated after show glow" (M. Galloway, Momreal Sirat, Oct. 16 1974). Richard Donat. who played Cuirette. attrihuted this to the play"s naivety claimung that the "play wats not as depraved as New York" (B. Kirkland. Sitar, Jan. 11 1977).

7. The play was produced in 1977 at the Nervous Breakdown coffechouse hut no reviews could be found.

8. According to M. O'Neill-Karch and P.P. Karch, the platy hat hece produced previously at the Tarragon

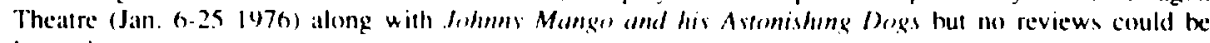
localted.

\section{RFFERENCFS}

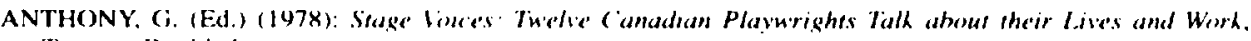
Toronto. Doubledily.

BL.ODCEETI, D. (198.3): "How do you say (iabriclle Roy?". Translation in (andian Liferature, Otawa, liniversity of Chawa Press. 
BOSLEY, V. (1980): "Diluting the Mixture: Translating Tremblay's Les Belles-Supurs". Traduction, terminologic, rédaction, 2:2, pp. 139-145.

BRAULT. J. (1975): Poèmes des quatre cótés, Chambly, Éditions du Noroit.

BRISSET. Anne (1990)): Sociocritique de la traduction : théatre el alterité au Québec (1968.1988). Longueuil. le preambule. $347 \mathrm{p}$.

DANCY. P. (1985): Tremblav at Tarragon 1972.1981: The Plays. the Produrtions and the Crifics, Masters Thesis, University of Guelph.

GLASSCO, B. (1978): "Michel Tremblay: A Unique Vision". Toronto Daily Star, January 16.

HOMEL. D. and S. SIMON (1988): Mapping Liserature, Montreal, Véhicule Press.

KOUSTAS. J. (1991): "From (iélinas to Carrier: Critical Response to Translated Quebec Theatre in Toronto". Unpublished manuwript.

L.EONARD, P'. (1988): "Critical Questioning", Canadian Thearre Revien', 57, Winter, pp. 4-10)

O'NEIl.L-KARCH. Marie and Pierre Paul KARCH (1984): "Le theátre québécois à Toronto", Revue d' historire litteraire du Québer le thédrre. Ottawa, Éditions de l'Université d'Ottawa.

STEINER, (i. (1975): Afier Bahel. Aspects of Language and Translation, New York and London. Oxford University Press.

USMIANI. R. (1979a): "Discovering the Nuance", Canadian Theatre Review, 24, Fall, pp. 38-41.

USMIANI. R. (1979b): Where to Begin the Accusation". Canadian Thearre Ro'vien'. 24. Fall, pp. 26-37.

WALLACE. R. (1988): "Towards an Understanding of Theatrical Difference". Canadian Theatre Rerien'. 55. Summer. pp. 5-14.

WALLACE. R. (1990): Producing Marginality: Theatre and ('rificism in Canada. Saskatoon, Fifth House Publishers.

\section{Articles}

George Anthony, Toromto Sun, Sept. 13 1974: April 6, 1975.

Audrey Ashley. Oncusu Citizen, Oct. 71974.

Ed Bean, Varsury. Sept. 20 and 29 1974: OCt. 201974.

Dubarry Campeau, Telexram. May 81970.

Ray Conlogue, Glohe and Mail, Jan. 16 1978: Nov. 23 1979; March 17 1980: May 23 1980; April 21982

Ar Cuthbert, Sifar, April 231980.

Kaspars Deguze, Sun, June 1980.

Richard Eder. Ne'w York Times, Feb. 21978.

Joseph Frdelyi, Onaw'a C'inze'n. April 6 1975; Jan. 17 1978: April 15 1978; April 181978.

John Fraser, Cilohe and Muil. Sept. 14 1974; Oct. 23 1975.

Brian Freeman, Siar. Jan. 15 1978: April 1.51978.

Myron Galloway. Montreal Siar. March 4 1973: June 11 1974: Oct. 161974

Kalherine (jilday. Star. March 16 1980.

Gegory Gilover. Sun. April 2 1974: May 171974.

Norma Harris, Globe' and Mail, Feb. 201982.

John Hebert, Onion, Feb. 15 1977; Feb. 161977

Bryan Johnson, Globe and Mail, May 151978.

Jack Kapica, (ilohe and Mail, Jan. 141977.

Urjo Kareda, Toromo Daily Star. May 12 1972; May 15 1972: Nov. 15 1972; Nov. 24 1972: Nov. 27 1972:

Dec. 7 1972; March 4 1973; April 4 1973; March I 1974; March 8 1974; May 16 1974: Feb. 3 1975:

June 5 1975: June 15 1975.

Bruce Kirkland, Star, January 111977

Agnes Kruchio, Evralıbur, Setp. 191974.

Roher MacDonald. Sun. April 81972.

Gina Mallet. Star. January 14 1977; Nov, 23 1979; June 5 1980; Feb. 19 1982: April 21982.

David McCaughna, Motiun. July / Aug. 1974.

David McCaughna, Tormento (ifizen. March 20 1973; March 12 1974; March 29 1974: Oct. 231975.

Stephen Mezei, Omom. Feb. 8 1978.

David Ossea, larsit: Jan. 2 1977: Jan. 211977.

(harles Pope, Siene (hanges, January 1977.

M. Porter, Sun, Oct. 24 1975: Jan. 17 1977; Jan. 16 1978: Nov. 251979.

Jamie Porter, Calgary Herald, April 301978.

Dan Rubin. Star, May 81970.

Dehra Sharp. (ilobe and Mail, June 61980.

11. Whittaker, (ilobe und Mail. May \& 1970): May 12 1972: Nov. 15, 1972; Nov. 24 1972; March 4 1973; March $\times$ 1974. April 1 1974: May 15 1974: May 16 1974: April 7 1974: Feh. 3 1975; June 51975.

John Wilson. Vurrsiry. Nov. 141975. 